\title{
What is a Relational Virtue?
}

Penultimate version - Final version forthcoming in Philosophical Studies

Please cite the published version

\begin{abstract}
In this paper, I introduce what I call relational virtue and defend it as an important subcategory of virtue. In particular, I argue that it offers a valuable resource for answering questions concerning the value of intimate relationships such as parent-child relationship or friendship. After briefly sketching what I mean by relational virtue, I show why it is a virtue and in what sense we can meaningfully distinguish it from other sorts of virtue. I then describe some distinctive features of relational virtue in more detail and discuss their implications. Next, I present filial piety as the paradigmatic example of relational virtue. I argue that a child's being filial should be understood as an appropriate response to her parent's being virtuous as a parent. I conclude by showing how my relational virtue theory of filial piety can avoid the difficulties faced by previous theories of filial piety such as gratitude theory and friendship theory.
\end{abstract}

\section{Introduction}

In this paper, I introduce what I call relational virtue and defend it as an important subcategory of virtue. In particular, I argue that it offers a valuable resource for answering questions concerning the value of intimate relationships such as the parent-child relationship or friendship. After briefly sketching what I mean by relational virtue, I show why it is a virtue and in what sense we can meaningfully distinguish it from other sorts of virtue. I then describe some distinctive features of relational virtue in more detail and discuss their implications. Next, I present filial piety as the paradigmatic example of relational virtue. I argue that a child's being filial should be understood as an appropriate response to her parent's being virtuous as a parent. I conclude by showing how my relational virtue theory of filial piety can 
avoid the difficulties faced by previous theories of filial piety such as gratitude theory and friendship theory.

\section{What is a Relational Virtue?}

Human lives are woven together and we rarely live in isolation. Most of us have people who are near and dear to us. Many of us also had those who were near and dear in the past and anticipate having other people become near and dear to us into the future. The relationships with our intimates - such as family members and friends - are an important part of our well-being and living a good human life. But not all intimate relationships are equally good. While some intimate relationships make our lives more enjoyable and meaningful, others are exhausting or even destructive. It also takes a great deal of effort to develop, sustain, deepen, and repair intimate relationships. Still, engaging in 'healthy' intimate relationships is partly constitutive of human flourishing. What makes an intimate relationship a good one of its kind? I suggest that, in an ideal intimate relationship, each participant would have the corresponding relational virtue.

So, what is a relational virtue? Roughly put, it is a virtue required for an individual as an excellent participant of the given type of intimate relationship. The examples of relational virtue include filial piety, parental virtue, or the virtue of friendship (i.e., a good friend's virtue). Intimate relationships generate normative demands, responsibilities, or expectations on their participants since intimates have a great influence on each other's flourishing in a special way. A relational virtue refers to excellence in relation to one's intimates and the relationship with them. Thus, a person who has a relational virtue has proper sensitivity to those normative demands and appropriate modes of responsiveness to them. For example, a relationally virtuous child would manifest a special willingness to help her parents when needed and a relationally virtuous friend would have a strong negative affective response to the very idea of betraying her friendship.

The functions of relational virtue involve developing, sustaining, deepening, and repairing the relationship with her intimates in an excellent way since relationships are 
dynamic - they deepen, they go stale, they fade away, they get damaged. Given the complexity of these functions, we can also say that a relational virtue involves an element of discernment or wisdom, one that guides its bearer in the intelligent management of her intimate relationships.

A relational virtue cannot be fully understood without reference to the particular type of intimate relationship and it presupposes and can be properly cultivated or exercised only within that relationship. Filial piety, for example, presupposes a parent-child relationship, since one can be filial only to one's parents, not to anyone else. Relational virtues are to be considered centrally in evaluating a given intimate relationship since an ideal intimate relationship of a kind would be one in which each of those involved in the relationship has the corresponding relational virtue.

\subsection{Is it a Virtue?}

One may ask whether what I call relational virtue is a virtue at all. I believe so because they have features that are typically attributed to a virtue. Let me begin with introducing Christine Swanton's definition of virtue, which is intended to be neutral with respect to a wide variety of virtue theories and virtue ethics: "A virtue is a good quality of character, more specifically a disposition to respond to, or acknowledge, items within its field or fields in an excellent or good enough way" (Swanton 2003, 19). Here the field of a virtue "consists of those items which are the sphere(s) of concern of the virtue, and to which the agent should respond in line with the virtue's demands" (Swanton 2003, 20). On this definition, a relational virtue can be understood as a virtue that has one's intimates and the relationship with them as its field. Just as courage and justice are virtues whose spheres are, respectively, fear of important damages and distribution of limited resources, so can filial piety, which I take to be an example of a relational virtue, be understood as a virtue whose sphere is the relationship with one's parent.

The view that filial piety is a virtue finds its strong support in the Confucian tradition, which emphasizes the social and interpersonal character of human life. According to the 
Classic of Filial Piety, for example, the virtue of filial piety is "the root of virtue and all [ethical] teaching grows out of it" (Legge 2004, Ch.1). ${ }^{1}$ Chenyang Li even says, “one cannot understand traditional Chinese culture without understanding the role of filial morality" (Li 1997, 219). P. J. Ivanhoe also follows this tradition in arguing that filial piety should be viewed as a virtue:

If, as some argue, virtues are traits of character that help one fare well in the face of a common set of human challenges, defined in terms of particular spheres of activity, then filial piety should be a central concern. For in one way or another, as human beings, we all have to work our way through the special relationship we have with our parents. While traditional beliefs about filial piety may be out of date, the fact that humans have an enduring, distinctive, and emotionally charged relationship with their parents remains as true today as it was in the past and as true in the West as it is in the East. (Ivanhoe 2007, 297; emphasis added $)^{2}$

Although I do not endorse every aspect of the Confucian conception of filial piety, I believe the concept of relational virtue can help us to capture important aspects of filial piety and other similar virtues. ${ }^{3}$ Within the sphere of the parent-child relationship, there are better and worse ways to be someone's child. ${ }^{4}$ Being a good child in relation to one's parent is a matter of excellence within the given sphere. This excellence has normative significance insofar as it enormously affects the parent's flourishing as well as one's own. A similar point can be made about other relational virtues such as parental virtue or the virtue of friendship since human beings typically have to deal with various intimate relationships including parent-child relationship and friendship.

\footnotetext{
1 See also Confucius's Analects: "Might we not say that filial piety and respect for elders constitute the root of humaneness (ren)?" (Confucius 2003, 1.2.).

2 Ivanhoe acknowledges that he owes this conception of virtue to Nussbaum (1993).

${ }^{3}$ For recent discussions on the Confucian conception of filial piety, see, for example, Sarkissian (2010), Huang (2013), and Radice and Goldin (2017).

${ }^{4}$ Of course, there are better and worse ways to be someone's parent. A good parent would be loving, caring, considerate etc., while a bad one would be overbearing, indifferent, abusive, etc. However, since I focus on filial piety in this paper, parental virtue or vice will be discussed briefly only in relation to the discussion of filial piety.
} 
Relational virtue also has other central features of a virtue. First, it is often claimed that a virtue should benefit its possessor (e.g. Hursthouse 1999). It seems reasonable to suppose that having a good relationship with one's intimates makes an important contribution to one's living a flourishing life as a human being. Assuming this, if a relationship is good to the extent that each participant is relationally virtuous, having the relevant relational virtue would contribute to having a good relationship with the given person. A relational virtue tends to benefit its possessor by ensuring the effective development and sustenance of intimate relationships that are both instrumentally good and intrinsically valuable. A person who has a good relationship with her family, for example, would be more likely to be socially successful and maintain good mental health. Therefore, there is an obvious sense in which relational virtue benefits its possessor.

Moreover, it is often believed that virtues are supposed to be intrinsically admirable in some sense. ${ }^{5}$ There are stories about parents who sacrifice themselves to save their children or people who trust their friends even in adversity. We tend to admire those people and their character traits independently of whether they serve to promote any goods that are external to their relationships. We tend to admire a filial daughter or trustworthy friends at least partly for their deep commitment to their intimate relationship. ${ }^{6}$ Note that this sort of admiration is distinct from one that we feel in relation to skills unrelated to virtue such as excellent athletic abilities. In this sense, the intrinsic admirability of a relational virtue is that of a moral virtue. Thus, it seems reasonable to believe that a relational virtue has some sort of intrinsic admirability.

Relational virtue also fits with the claim that virtue is a stable disposition of character, as opposed to a short-term attitude, which means that the disposition is expressed across a range of different situations, even in adverse conditions. A filial child, for example, is one who is stably disposed to feel certain kinds of emotions - typically love, gratitude, and respecttoward her parents and act in a way that expresses such emotions. Those filial attitudes and

\footnotetext{
${ }^{5}$ For example, Julia Annas claims that virtues are "dispositions worthy of a distinct kind of admiration, which inspire us to aspire to them as ideals" (Annas 2011, 6).

${ }^{6}$ Of course, on the assumption that their commitment does not violate general moral requirement for others. But this would be a requirement for any admirable person's story. One may admit the possibility of admirable immorality, but that possibility does not undermine my point here.
} 
actions should come from her stable character rather than whimsical mood or feeling. If someone has such 'filial' attitudes only when she is in a pleasant mood or her parents give her valuable gifts, it would be inappropriate to attribute the virtue of filial piety to her. In this sense, filial piety and other relational virtues are a kind of stable disposition.

\subsection{Is it a Distinctive Kind of Virtue?}

Even assuming that relational virtue is a virtue, someone might still wonder if it is a distinctive kind of virtue that merits a separate inquiry. My answer is yes. A good justification for a claim that a certain quality of character is a virtue of a distinctive category that merits its own name would be to show how such a separate treatment can enhance our understanding of it. I am proposing the category of virtues called relational virtue because in that way we can better understand the ethical importance and remarkable characteristics of the virtues in this category. For example, I believe we can enhance our understanding of filial piety by seeing how it is different from virtues in other categories such as benevolence and honesty. Thus, let me focus on highlighting the distinctive features of a relational virtue, rather than on offering some metaphysical ground that separates it from other kinds of virtues. ${ }^{7}$

It would be helpful to begin by considering the familiar distinction between selfregarding and other-regarding virtues. A self-regarding virtue like temperance neither requires any other person as its intentional object nor implies benefiting someone else in any way. By contrast, an other-regarding virtue like generosity conceptually requires some other person as its intentional object, and the success in exercising this sort of virtue depends on how the target person is affected. While relational virtues can be seen as a kind of otherregarding virtue, not all other-regarding virtues are relational in my sense. Interestingly, what I call 'other-regarding virtues' fits the description of what Shirong Luo calls 'relational virtues'

\footnotetext{
7 In fact, for those who are committed to the thesis of the unity of virtue-i.e., the thesis that if you have one virtue you have all the others-any categorization or individuation of virtue would have no metaphysical grounds. While I remain neutral with respect to the thesis of the unity of virtue, I would like to emphasize that introducing the category of relational virtue has a meaningful theoretical advantage.
} 
in the context of comparing the ethics of care and Confucian ethics (Luo 2007, 102-107). So it would be helpful for clarifying my conception of relational virtue to compare it with the one Luo uses. He understands a 'relational virtue' as one that requires someone else as its intentional object. Thus, it cannot be fully understood without reference to another person(s) and cannot be properly cultivated or exercised without their existence. For example, generosity requires someone else who needs a certain kind of good and thus one cannot have the virtue of generosity without any potential recipient of good that one gives.

By contrast, I reserve the term 'relational virtues' for a distinct subcategory of otherregarding virtues. Unlike such unilateral other-regarding virtues, relational virtues presuppose particular intimate relationships between the virtue-agent-i.e., one who exercises the virtue-and the virtue-patient-i.e., the intentional object of the virtue. Relational virtues in my sense require more than the minimal relation of the virtue-agent and the virtue-patient as its target. They are appropriate for certain intimate relationships, such as parent-children relationship or friendship, and cannot be fully understood without reference to particular relationships and can be properly cultivated or exercised only within those relationships. So understood, relational virtues form a subcategory of virtue that is significantly different from both self-regarding virtues and other sorts of other-regarding virtues.

Relational virtues can also be distinguished from general virtues, by which I roughly mean the virtues that concern the disposition in relation to people in general-such as benevolence or generosity-as opposed to particular people. The distinction between being virtuous to people in general and being relationally virtuous or virtuous to one's intimates is supported by the observation of familiar examples around us. We can find people who are virtuous in relation to people in general but not in relation to their intimates or vice versa. There are people who are very selfish and callous to strangers but deeply altruistic and caring in relation to their own family and friends. Don Vito Corleone in the movie, The Godfather, is one example of such a person. While he is quite caring and generous within his 'family,' he is callous and even cruel outside of this narrow circle. On the other hand, we can also find the case where someone is largely generous and altruistic to strangers but not very nice and kind to one's own intimates. For example, Mahatma Gandhi, who was widely admired as a sagelike figure by his country and even by the world, was known to be a bad father to his own son. 
While people are often partial in favor of their intimates, they can also be cruel-or cruelerto their intimates, since the very closeness and intimacy creates new possibilities for more acute pain, neglect, abandonment and so on. The important point here is that our attitude toward our intimates is often very different from the attitude toward those who are outside of the inner circle.

One may ask if relational virtues are a distinctive subcategory of virtue or a form that certain virtues could take. A simple answer might not be available because the relationship with relational virtues and other virtues is quite complicated. But a rough version of my answer is that a relational virtue is a distinctive sort of virtue constituted by a set of specialas opposed to general-forms of virtues that are 'tailored' to the particular intimate and the relationship in question. It is true that a virtue like filial piety shares some elements of virtues like benevolence, understood as involving the attitude of willingness to promote the target person's well-being. However, the special form of benevolence that filial piety as a relational virtue requires would be different from the general version of benevolence that we have toward people in general including strangers. Similarly, gratitude is widely understood as an appropriate attitude we have in response to some benefit offered by someone else. But the special form of gratitude we owe to our parents for being good parents would be different from the gratitude we owe to a stranger who happened to find our lost wallet for us.

To further clarify my point, let me give a basketball analogy. If general virtues such as benevolence are compared to general athletic abilities such as strength and agility, relational virtues such as filial piety can be compared to the set of qualities required to be a good basketball player. Although physical strength and agility can help someone to become a good basketball player, they should be tailored in a way that contributes to the team's winning. For example, strength should be used for making accurate three-point shots even from a distance and agility should be used for penetrating defenders with dribbling. Simply being strong and fast is not enough for being a good basketball player. These qualities of a good basketball player are analogous to the relationship-specific elements of filial piety such as special love and gratitude towards one's parents. I will discuss this specialness of relational virtues in more detail in the next section. 


\subsection{Characteristic Features of Relational Virtue}

I have argued that relational virtues are virtues and that they are meaningfully different from other types of virtue. There are some further features of relational virtues that are not shared by other sorts of virtue. Many of these features are to be understood in terms of the characteristic features that good intimate relationships have. In this section, I highlight some such features of relational virtues by examining what constitutes a good intimate relationship and what a relationally virtuous person would be like.

Some characteristic features of relational virtue can be understood in terms of particularity. Being relationally virtuous involves acting, desiring, and feeling appropriately with regard to particular persons with whom you share the relevant intimate relationship. In this sense, one's relational virtue is 'indexed' to a particular person or persons who hold the intimate relationship in question. ${ }^{8}$ This point shows the sense in which cultivation and exercise of relational virtues presuppose particular relationships with particular individuals. In contrast, general virtues like generosity can be cultivated and exercised in relation to any other person in need, including a stranger. ${ }^{9}$

This particularity allows relational virtues flexibility with regard to social or cultural expectations, including gendered ones. For relational virtues should be tailored to the given particular relationships. For instance, filial piety understood as a relational virtue defies the idea that the role of a child to her parents is fixed generally by the social norms about a good child's role. There are various particular ways for one to be filial to one's parents in the given conditions. The fact that a certain society normally expects mothers to contribute more to caring and nurturing than fathers does not imply that filial piety should reflect such a social expectation. ${ }^{10}$ For example, if Giannis's father did more work of caring

\footnotetext{
${ }^{8}$ Laurence Blum makes a similar point about friendship: "What we do for our friends is very particular to our relationship to them, both in the sense of being particular to friendship as a type of friendship, and in being particular to a particular relationship with a particular person" (Blum 1980, 56).

9 David Solomon also hints the possibility of a virtue with exclusive object: "A virtue must be somewhat general, but this generality need not entail that the virtue be impersonal, much less dispassionate, nor need it preclude exclusivity with regard to its object" (Solomon 2005, 87; emphasis added).

10 This is why I use gender-neutral terms such as 'parent-child relationships' or 'filial piety' as opposed to 'father-son relationships' or 'daughterhood.'
} 
and nurturing him than his mother, his filial love and gratitude that constitute his filial piety can be tailored accordingly. Filial piety as a relational virtue is in this sense less likely to be corrupted by biases entrenched in society or wider structures of inequality.

The particularity of relational virtues also implies that intimate relationships are unique or irreplaceable in the sense that no one else could have the given relationship with that person. For example, if Rabia cuts off or lets slide the relationship with her father Ahmed and never resumes, he would lose this particular relationship forever since no one else can assume Rabia's role as his daughter. This irreplaceability highlights the importance of relational virtue, since failing to be relationally virtuous would have an irrevocable deep-usually negative-impact on the given intimate's life.

The next characteristic feature of relational virtue is specialness. A relational virtue demands the agent to regard and treat the intimates in question as someone special, that is, as someone who shares a special relationship with the agent herself. Treating someone as special involves prioritizing that person over others and giving more weight to her interests than to others. For instance, you would attend your close friend's wedding but not a stranger's. A relational virtue also involves having a special kind of emotional and motivational attitude toward the intimate in question. For example, parents want special love from their child, as opposed to impartial altruistic care, which she can have towards any other person. ${ }^{11}$ Suppose that Alicia takes care of her sick father from a merely altruistic motivation - that is, that she serves him purely for his own sake without ulterior motives. But insofar as this benevolent act is done out of general human sympathy and compassion for him merely as another human being in need, not as her own father who is special to her, there seems to be something missing in her motivation as a filial person. ${ }^{12}$

As I have mentioned above, one merit of introducing the concept of relational virtue

\footnotetext{
${ }^{11}$ Lawrence Blum makes a similar point about friendship: "In friendship one desires and acts for the good of the friend, not simply because he is another human being but precisely because he is one's friend." (Blum 1980, 44)

12 The Confucian tradition also emphasizes the moral importance of having a special or partial-as opposed to general or impartial-attitude toward one's intimates. For example, Mencius claims that the exemplary person (junzi) is humane (ren) toward the people but does not treat them as kin (qin) (Mencius 2011, 7A45). Here ren refers general virtue toward people and qin refers to special affection.
} 
is that it helps us to capture the admirability of character traits in those who are regarded as, say, good friends or good children, which is distinct from being benevolent or generous in a general sense. If, for example, we understand Alicia's hearty care for her sick father as just another case of benevolence, we would miss the distinctive admirability involved in her filial piety. If the agent does something in favor of someone not because she takes him or her as someone special to her (e.g., father or friend), but because of some impartial considerations, then this specialness would evaporate. Take Michael Stocker's famous example. If you visit your friend in the hospital not because you think of her as your friend (i.e., as someone special to you) but because you think that it would be the best way to maximize the general happiness or to fulfill your moral duty, then your friend would be rightly disappointed by your motivation to visit her (see Stocker 1976).

Other distinctive features of relational virtue concern its dependency. Part of what makes a relational virtue a virtue is the fact that it is constitutive of virtuous relational activities in intimate relationships. By relational activities, I roughly mean interactivity between intimates qua intimates, broadly construed-such as having deep conversations, exchanging gifts, helping each other when either is in need, and so on. Without other participants, however, one cannot even engage in any relational activity at all, let alone a virtuous one. Moreover, the mere existence of intimates is not sufficient to engage in a virtuous relational activity; the excellence or 'virtuousness' of a relational activity also depends on how relationally virtuous the participants of the given relationship are. If the other participant lacks relational virtue, one's being relationally virtuous would not be sufficient to make the relationship an ideal one.

To show these points more clearly, let me use a soccer analogy. An excellent soccer player is one who has the ability to contribute to her team's winning. First, one cannot even play soccer at all, let alone winning the game, without other team members to play in the game together. But if she is the only one who plays well and other players are far below her in their skills, her individual skills are unlikely to be sufficient to make the team win the game. Of course, she alone may be able to show impressive individual performance. But that would be pointless for her as a soccer player insofar as it is not sufficient for the aim of winning the 
game. ${ }^{13}$

Similarly, without the other participant, we cannot engage in any relational activity at all and the excellence of the relational activity is partly determined by that other participant's relational virtuousness. If virtuous activities are constitutive of human flourishing, and if virtuous relational activities are an important part of them, it follows that an important aspect of human flourishing is fragile in a distinctive way. That is, the flourishing of a participant in the relational activity is dependent on and thus vulnerable to the other participant's character and agency in a significant way. For example, if your parents are abusive, cruel, and indifferent to you, you will be deprived of an important opportunity to engage in virtuous relational activities with your parents.

One might worry that these features of a relational virtue make our ability to engage in virtuous activities a matter of luck to a greater extent than we should feel comfortable with. Although I do understand the 'vertigo' one might feel when one realizes how big a role luck plays in our lives, I think this is the reality that we need to admit, and an adequate ethical theory should be able to embrace it. That is, I believe that important aspects of human flourishing are vulnerable to the element of luck and the introduction of a relational virtue helps us to see how.

Note that a virtuous relational activity in a good intimate relationship is neither onesided nor based on a prudential give-and-take mentality. First, a one-sided relationship is at least less desirable than its reciprocal version. Thus, for example, one-sided love is not sufficient to engage in an excellent relational activity. This point is supported by the very fact that what the person in one-sided love wants is precisely to have a reciprocal loving relationship with the one she loves. Nor is a prudent give-and-take mentality sufficient for virtuous relational activity. Although relationships based on such a mentality involve some sort of reciprocity and interactivity, that does not lead us to an ideal intimate relationship. In particular, such relationships would not be intimate, perhaps not even personal. Consider a business partnership. What defines the relationship between business partners is the

\footnotetext{
${ }^{13}$ Note that, by contrast, if she were a tricks-soccer player, whose internal aim is performing exquisite soccer tricks for entertainment, her individual skills would be sufficient for achieving that aim.
} 
calculation of gain and loss and interaction based on it. It may be possible that two persons are business partners and friends at the same time. But what makes their relationship go beyond business partnership to reach friendship is precisely that their interaction involves more than mere prudent give-and-take.

Note that relational virtues are different from loyalty, although loyalty seems to share its characteristic features suggested above, such as particularity and specialness. According to the definition in the Stanford Encyclopedia of Philosophy, loyalty is

a practical disposition to persist in an intrinsically valued (though not necessarily valuable) associational attachment, where that involves a potentially costly commitment to secure or at least not to jeopardize the interests or well-being of the object of loyalty. (Kleinig 2017, sec. 2.)

I believe that a relational virtue is different from loyalty in several important aspects. First of all, one can be loyal to almost anything one can be attached or committed to-from persons or personal collectives such as social groups to non-persons such as principles or causes. In contrast, the target of a relational virtue is persons exclusively. Even if we focus on loyalty to persons, loyalty is different from a relational virtue in that it can be unilateral and does not presuppose an interactive relationship between the persons in question. For example, one can be loyal to a pop star even when she is not aware of one's existence.

A relational virtue is also different from loyalty understood as a character trait, that is, as "a tendency to form particular bonds of loyalty and act in their light" (Keller 2007, 155). When we say someone is a 'loyal' person in a general sense, what we usually mean is that loyalty plays a significant role in her life. However, loyalty understood this way is significantly different from a relational virtue. As I have said, a relational virtue is 'indexed' to particular individuals and thus in this sense local. In contrast, loyalty as a character trait is general in that it describes a general tendency to be loyal to the targets who happen to form a special relationship with. Thus, unlike relational virtues, it neither presupposes a special intimate relationship nor is indexed to particular persons. 


\section{Filial Piety as a Relational Virtue}

With the concept of relational virtue in hand, let me propose my relational virtue theory of filial piety. Filial piety has been an important topic in the Confucian tradition and there have been revived interests in this topic among contemporary Western philosophers. I believe my idea of relational virtue can help us to better understand this virtue in a way that captures the 'spirit' - though not necessarily the 'letter' - of Confucianism while avoiding the difficulties faced by contemporary Western theories. Filial piety is a virtue required for a child as the participant of her parent-child relationship, fits neatly with my characterization of relational virtue. It cannot be fully understood without reference to the parent-child relationship and can be properly cultivated or exercised only within this relationship. The child can be filial only in relation to her parents, not others. A desirable parent-child relationship is one in which the child is filial, and the parent is parental (or parentally virtuous). If the child is not filial, then the parent-child relationship in question is defective in that regard. I think my view of filial piety, which can be called the relational virtue theory of filial piety, has an advantage in capturing the relational aspect between the parents' parental virtue and the child's filial piety.

\subsection{Parental Virtue and Filial Piety}

So far, it has been assumed that the parents in question deserve their child's filial piety. But what if the parents are not sufficiently good parents, and thus do not deserve to have a filial child? It seems unreasonable to claim that a child should have love, gratitude, and respect, no matter how terrible her parents are. My relational virtue theory, which emphasizes the reciprocal nature of filial piety, does not impose such an unconditional requirement on a filial child. According to my theory, a child's being filial is required as an appropriate response to the parent's being parental. In other words, the normative ground for the requirements of filial piety is the relational virtuousness of one's parents. 
It might appear that my theory thus recommends us to refrain from being filial to the extent that the parents are defective as parents, keeping the exact proportionality between parental virtue and filial piety. However, this is not what my theory implies. It only suggests that the requirements of being filial can vary according to the degree of the parents' relational virtuousness and the relationship between the child and the parents and that one would have a reasonable excuse for not being filial if one's parents are not sufficiently good as parents. It is true that most parents in the real world are neither exemplary nor despicable as parents. It is also true that my top-down approach focuses on describing ideal cases, where the parents are parentally virtuous and the child is filial. However, I believe my theory has rich resources to give answers or at least guidance to questions concerning the normative ground of filial piety in non-ideal cases, where parents are not perfectly parental.

To begin, a relational virtue itself involves a reasonable degree of forbearance, which enables the agent to keep being relationally virtuous to the intimate in question even if the intimate does not possess the corresponding relational virtue. This implies that a truly filial child would try to care about her parents even if they are not perfect parents. Such forbearance would be an important part of filial piety in a non-ideal parent-child relationship. First, it is needed in the process of developing the intimate relationship between the child and the parents at its early stage. Second, such forbearance would play an important role in helping one's parents to become more virtuous as parents. Recall that the goal of filial piety as a relational virtue is to have a good relationship with parents and engage in virtuous relational activities with them and that such activities require both participants to have corresponding relational virtues. If so, it would be reasonable to hold that filial piety involves reasonable forbearance in relation to one's parents at least in a non-ideal case where the parents are not fully virtuous as parents.

In addition, my theory is compatible with other possible reasons-perhaps the reasons that do not directly stem from the demand of filial piety - to be filial to one's parents even if they are defective as parents in some ways. For example, suppose that Dan's parents provided him with material and financial support motivated by self-interest, rather than by love and care for him. In this case, Dan has a reason to repay what he has received from his parents, say, by providing material and financial support when they become old and infirm, 
just as a truly filial child would do to her loving and caring parents. However, Dan's reason to support his parents derives from the general principle that we ought to pay back what we owe to someone, not from the norms of filial piety in particular. In this sense, Dan's supporting his parents is not an expression of the virtue of filial piety but just fulfilling the general duty to repay one's creditor. Still, it gives him a reason to act as a filial person would do to her loving and caring parents, although Dan's reason for doing so would differ from hers.

Also, consider the case of Chan. Although his parents have not been extremely abusive or cruel, they did not offer adequate protection, nurturance, and support to him. It is not because they are in financial difficulty or physically incapable, but just because they care more about their enjoying luxurious leisure time than taking care of their son. That is, they failed to act virtuously as parents due to the defect in their character. However, Chan may have a reason to act filially to his parents as if they have been fully parental to him. He may act filially-e.g., pay for his parents' hospital expenses and contact them frequently-just because he felt a general feeling of sympathy for someone in need or because he wanted to set a good example of filial piety to his own daughter. Although these reasons may not be properly called the reasons of filial piety in a strict sense, it is compatible with my theory to recommend to act as a filial person would act for such reasons.

Of course, according to my theory, a truly filial person is one who acts filially out of love, care, and gratitude, not merely for reasons external to filial piety. In an ideal case, the parents would be parentally virtuous and the child would be filial. Thus, in non-ideal cases where parents lack parental virtue, it would be hard to realize a desirable parent-child relationship just based on the efforts from the child's side. Still, it is one thing to say that the failure of being filial to despicable parents is excusable, and it is another to say that being or trying to be filial even to defective parents is not morally recommendable or praiseworthy. My theory can acknowledge that it is morally recommendable or even admirable for the child to keep trying to be filial to her parents even if they do not fully deserve it. Such a person would be admirable in the similar sense that a victim who forgives and embraces the assailant even if she has a good reason not to do so-that is, the fact that the latter unjustifiably harmed the former.

It is important to note that my theory does not demand a person to be filial to her 
parents even when they are extremely vicious as parents - e.g., abusive, derelict or oppressive. Consider the story of the sage-king Shun in ancient China and his vicious parents (see Mencius 5A1-2). Shun's parents were far from being virtuous as parents. They not only hated Shun but even attempted to kill him multiple times by burning the granary when he was on its roof and by asking him to dig a well and then covering it over. In an extreme case like Shun's, my theory recommends against being filial because demanding him to love, thank, and revere such vicious parents can amount to demanding him to commit himself to the vice of servility and abandon self-respect.

We can also consider the case where one's parents fail morally as persons in a general sense, not necessarily as parents. What should we do if our parents do or tell us to do something morally wrong? These and related questions have been an object of heated debates in the Confucian tradition. ${ }^{14}$ I think Mencius's view on this issue is particularly relevant to our discussion (Mencius 2011, 7A35). He says that, if the sage-king Shun's father commits a serious crime, Shun would abandon his position as a king - so that he is not bound by the impartial role as a king - and run away with his father - so that he can meet the demand of filial piety as his son. I think we should pay more attention to how Mencius approaches this issue than to his solution itself. Whether his solution is plausible or not, I believe that Mencius was right to acknowledge the demand of filial piety as a virtue that competes with the demand of other moral virtues. This approach captures one of the main reasons why I introduce the idea of relational virtue is to argue that its demand should compete with the demands of other virtues - such as general benevolence or justice-as one of important moral considerations.

To give an idea of how my relational virtue theory approach this issue, let me give an example. Suppose that Luka's parents, who love and care for him, espouse sexist and racist views. If so, because they have been good parents for him, filial piety requires him to do something for their own sake out of care. At least, doing nothing about their morally

\footnotetext{
14 For example, Confucius suggests that "uprightness" lies in the child's covering up her parent's wrongdoing (Confucius 2003, 13.18), while Xunzi suggests that a filial child may go against her parents' orders if that is the way to protect them from committing themselves to danger, disgrace, or something beastly (Xunzi 2014, Ch. 29). For a recent reflection on this issue, see Li (2008).
} 
objectionable views would render him less than fully filial. Luka, as a filial child, may try to convince them that sexism and racism are morally objectionable and gently remonstrate them against holding and acting on such views. If they do not change or even respond in a hostile way, he may stop advising them in vain while maintaining a good relationship with them. My theory does not necessarily imply that one should not be filial to them or should sever one's connection with one's parents whenever one's parents have some moral defects. According to my theory, many decent parents who are not morally perfect may still deserve to have a filial child. Of course, if the parents' moral defect goes to the extreme, my theory may advise that one should stop their wrongdoings or even end one's relationship with them. For instance, suppose that Acadia finds her parents to be cruel serial killers. In such a case, even if they have been quite good parents to her, she may have to stop loving and caring for them or even report them to the police. By considering filial piety as one of important moral virtues in this way, my theory can help us to have a more balanced view on cases where the norms of intimate relationships seem to conflict with broader social norms.

\subsection{Avoiding Difficulties}

Let me finish this paper by showing how my relational virtue theory can avoid the main difficulties of the existing theories of filial piety. The gratitude theory of filial piety claims that a filial child should express gratitude through appropriate acts in response to what her parents have done to her from benevolence (see, e.g., McConnell 1993, esp. Ch. VII). One important challenge against the gratitude theory is to show how to make sense of why we owe gratitude to our parents for what they have done to us even if we were too young to request or agree to receive them. This challenge assumes that only something that is received by the agent's request or choice can be an appropriate object of gratitude. My relational virtue theory can avoid this challenge because it holds that the kind of gratitude appropriate for a filial child is the gratitude to her parents for being caring parents, rather than just for what 
they have done to her. ${ }^{15}$ Sharing an intimate relationship with someone is not simply a matter of request or choice; rather, it is what happens as a result of a substantial history of favorable and meaningful interactivities.

Moreover, my theory does not have to explain why we owe gratitude to our parents if our parents were just fulfilling their duties as parents. In my view, being a good parent is a matter of cultivating and exercising parental virtue in relation to one's child, not just a matter of fulfilling their duties - e.g., providing protection, support, and education. Thus, filial piety requires some sort of reciprocity between the relational virtues in question-i.e., parental virtue and filial piety - rather than that between goods or favors exchanged. If so, since being a good parent is not just a matter of fulfilling one's duty, my theory can avoid the challenge that there is no reason to be grateful to someone when she is just fulfilling her duties.

Another important challenge to the gratitude theory is that the degree of the parents' sacrifice does not seem to affect filial duties while it does affect the gratitude we owe to them (see Keller 2006). The issue is this. It seems that a child has more duty of gratitude toward her parents when they have sacrificed a great deal and put a lot of effort into raising her than when they did not sacrifice as much and even enjoyed much in raising her. However, the requirement of filial piety to look after one's parents when they become old and infirm does not seem to be mitigated just because they have enjoyed parenting or have made less sacrifice.

I believe my relational virtue theory can address this issue. First, I believe the goods, efforts, and sacrifice the child owes to her parents is not fully determined by the goods, efforts, and sacrifice from the parent's side. Rather, what is importantly relevant in terms of the demand of filial piety is how parentally virtuous the parents are; that is, the child should be filial to her parents at least to a degree insofar as they have been reasonably decent parents. Thus, according to my theory, whether and how a child should be filial is not simply determined by the amount or quality of goods given or the efforts and sacrifice made by the parents. It implies that, if parents are reasonably virtuous as parents, the child may be required to be filial to them even if they have actually provided only a few goods to the child.

Even if some parents fail to give their children a decent upbringing, this fact does not

${ }^{15}$ For a detailed discussion on this distinction, see Um (2019). 
necessarily imply that the child is thereby mitigated in or exempted from the demand of filial piety. We should ask why the parents failed to give a decent upbringing. For example, if it is due to the poor social arrangement or lack of sufficient materials through no fault of the parents' own, it does not necessarily speak against their virtuousness as parents. On the other hand, if the reason for the poor upbringing is the parents' vicious character as parents-e.g., abusive, derelict, or oppressive - then it can provide the child with a reasonable excuse not to be filial to them. What is important here is whether the parents in question tried hard enough to offer the goods their children need in the given situation and whether they are parentally virtuous such that they would have provided the child the goods if the situation allowed. ${ }^{16}$ If the parents are sufficiently virtuous as parents, then the child in question would be legitimately expected to be filial to her parents and offer them the goods they need when she can.

A similar point can be made about parents' efforts or sacrifices. Suppose that Hak, a poor father, was rich enough to raise his daughter Chung without great efforts and sacrifice from his part. Other things being equal, does Chung owe less gratitude to this 'effortless' father than she would to the 'sacrificing' father? Again, what matters here is whether Hak is sufficiently virtuous as her parent. This can be gauged by considering whether he would have sacrificed for Chung if the circumstance were unfavorable, not necessarily by considering whether he actually made the sacrifice. Then, at least to that extent, Chung would be legitimately expected to be filial to Hak and offer him the goods he needs in the given situation.

People who support the duty-centered approach on filial piety may try to accommodate the intuition in this response by appealing to the concept of counterfactual or hypothetical duties. ${ }^{17}$ However, I am not sure if this kind of duty makes sense. For example,

${ }^{16}$ In a similar vein, Richards claims that the measure of the gratitude we owe them, should not be the sacrifice your parent actually makes for you, but "the sacrifices he would make for your sake if he were called upon to make" (Richards 2010, 232; emphasis added). However, my view is different from his because, while this counterfactual consideration in my view is to evidence the parent's parental virtue, in his view, it is to indicate the place the child has in her parents' affections.

17 Mark R. Wicclair mentions (although he does not discuss in depth) the possibility of these sorts of duties (or obligations): "For example, although I did not have polio as a child, since my mother would have been willing to make substantial sacrifices to help me if I did, it might be claimed that I should be willing to make substantial sacrifices for her if she were to develop Alzheimer's. If there are such obligations, they cannot plausibly be construed as duties (of gratitude) that are generated by (actual) past parental sacrifices, and they are therefore beyond the scope of this paper" (Wicclair 1990, 188, note 
while an actual promise generates a duty to keep the promise, a merely hypothetical promise does not. Similarly, while the actual sacrifices of parents for the child may generate a duty of gratitude, merely hypothetical sacrifices do not. At least, it seems hard to explain the sense in which it is a duty. In contrast, my theory can make a better sense of why the parents who did not actually provide certain goods or make sacrifices still deserve their child's filial pietyincluding gratitude. This is because what it requires of the parents is their having parental virtue and exercising it appropriately in the given context, rather than performing a specific kind of actions or providing a specific kind of goods. ${ }^{18}$ Note that being virtuous as parents does not necessarily require particular types of action unless the situation calls for them, just as a courageous person would still be courageous even if she hardly had any opportunity to express it because the world has been 'too' peaceful.

My relational virtue theory also avoids the main challenges against the friendship theory of filial piety. According to Jane English's version, the source of filial duties is the current relationship between parents and children, rather than what parents have done for the children in the past (see English 1992). Thus, what requires children to take care of and benefit their parents is the on-going friendship between them. One challenge against the friendship theory is that it implies that there is nothing the child ought to do to her parents when the loving relationship between them is gone, which makes it too easy to be exempted from the 'burden' of filial piety. My theory can avoid this problem because it does not require the existence of the current loving relationship per se for filial piety. At least insofar as the parents have been parental, the demand of filial piety cannot be avoided simply by choosing to leave the relationship since the child is required to be or at least strive to be filial to them in response to their virtuousness as parents.

\section{Conclusion}

In this paper, I have argued that relational virtue is a distinctive kind of virtue that

\section{4).}

18 See Christopher Wellman (1999) for a view that gratitude in general is better understood as a virtue rather than as a source of duties or obligations. 
has an ethical significance and introduced some characteristic features of relational virtue. Then I have proposed my own relational virtue theory of filial piety, according to which we should be filial to our parents at least to the degree that they are or have been virtuous as parents. I have also shown how my theory can avoid some main challenges against the existing theories of filial piety. Having good relationships with our family members and friends is very important for having a flourishing life as a human being. Our everyday experience seems to suggest that being relationally virtuous is not the same as being a good person in relation to people in general. If this is true, an adequate ethical theory should be able to distinguish the virtue in relation to one's intimates from general virtues and explain the distinctive feature of the former. I hope my idea of relational virtue can serve as a conceptual tool that can help us to see what good intimate relationships are like and how we can work to build such relationships. 


\section{References}

Annas, Julia. 2011. Intelligent Virtue: Oxford University Press.

Blum, Lawrence A. 1980. Friendship, Altruism, and Morality, International Library of Philosophy: Routledge \& Kegan Paul.

Confucius. 2003. Analects: With Selections from Traditional Commentaries. Hackett Publishing.

English, Jane. 1992. "What Do Grown Children Owe Their Parents?" In Aging and ethics, 147154. Springer.

Huang, Yong. 2013. Confucius: A Guide for the Perplexed: Bloomsbury Academic

Hursthouse, Rosalind. 1999. On Virtue Ethics: Oxford University Press.

Ivanhoe, Philip J. 2007. "Filial Piety as a Virtue." Working Virtue: Virtue Ethics and Contemporary Moral Problems:297-312.

Keller, Simon. 2006. "Four Theories of Filial Duty." The Philosophical Quarterly 56 (223):254274.

Keller, Simon. 2007. The Limits of Loyalty: Oxford University Press.

Kleinig, John. 2017. Loyalty. In Stanford Encyclopaedia of Philosophy, edited by Edward N. Zalta: Stanford.

Legge, James. 2004. The Hsiao King or Classic of Filial Piety: Kessinger Publishing.

Li, Chenyang. 1997. "Shifting Perspectives: Filial Morality Revisited." Philosophy East and West:211-232.

Li, Chenyang. 2008. "When my grandfather stole persimmons... reflections on Confucian filial love." Dao 7 (2):135-139.

Luo, Shirong. 2007. "Relation, Virtue, and Relational Virtue: Three Concepts of Caring." Hypatia 22 (3):92-110.

McConnell, Terrance. 1993. Gratitude: Temple University Press.

Mencius. 2011. Mencius. Translated by Irene Bloom and Philip J Ivanhoe: Columbia University Press.

Nussbaum, Martha. 1993. "Non-Relative Virtues: An Aristotelian Approach." The Quality of Life. 
Radice, Thomas, and Paul R Goldin. 2017. "Confucius and Filial Piety." A Concise Companion to Confucius:185-207.

Richards, Norvin. 2010. The Ethics of Parenthood: Oxford University Press.

Sarkissian, Hagop. 2010. "Recent Approaches to Confucian Filial Morality." Philosophy Compass 5 (9):725-734.

Solomon, Robert C. 2005. "Erotic Love as a Moral Virtue." In Virtue Ethics, Old and New, edited by Stephen Mark Gardiner. Cornell University Press.

Stocker, Michael. 1976. "The Schizophrenia of Modern Ethical Theories." The Journal of Philosophy:453-466.

Swanton, Christine. 2003. Virtue Ethics: A Pluralistic View: Oxford University Press.

Um, Sungwoo. 2019. "Gratitude for Being." Australasian Journal of Philosophy:1-12. doi: 10.1080/00048402.2019.1640259.

Wellman, Christopher Heath. 1999. "Gratitude as a Virtue." Pacific Philosophical Quarterly 80 (3):284-300.

Wicclair, Mark R. 1990. "Caring for Frail Elderly Parents: Past Parental Sacrifices and the Obligations of Adult Children." Social Theory and Practice 16 (2):163-189.

Xunzi. 2014. Xunzi: The complete text. Translated by Eric L Hutton: Princeton University Press. 